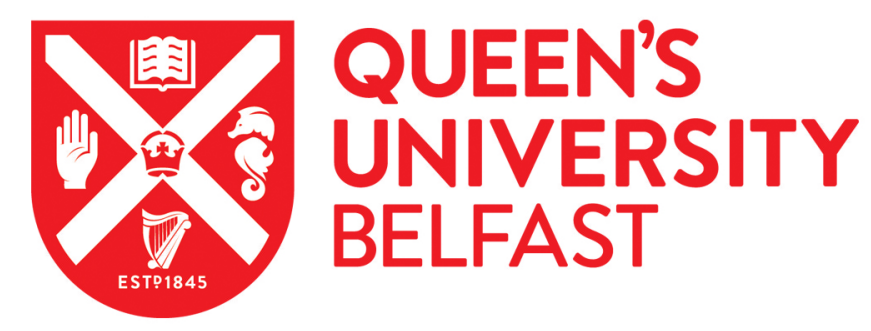

\title{
Clarification of rubber mill wastewater by a plant based biopolymer- comparison with common inorganic coagulants
}

Mukherjee, S., Pariatamby, A., Sahu, J. N., \& Sengupta, B. (2013). Clarification of rubber mill wastewater by a plant based biopolymer- comparison with common inorganic coagulants. JOURNAL OF CHEMICAL TECHNOLOGY AND BIOTECHNOLOGY, 88(10), 1864-1873. [DOI 10.1002/jctb.4041]. https://doi.org/10.1002/jctb.4041

Published in:

JOURNAL OF CHEMICAL TECHNOLOGY AND BIOTECHNOLOGY

Document Version:

Peer reviewed version

Queen's University Belfast - Research Portal:

Link to publication record in Queen's University Belfast Research Portal

Publisher rights

The copyright is owned by University of Malaya

\section{General rights}

Copyright for the publications made accessible via the Queen's University Belfast Research Portal is retained by the author(s) and / or other copyright owners and it is a condition of accessing these publications that users recognise and abide by the legal requirements associated with these rights.

Take down policy

The Research Portal is Queen's institutional repository that provides access to Queen's research output. Every effort has been made to ensure that content in the Research Portal does not infringe any person's rights, or applicable UK laws. If you discover content in the Research Portal that you believe breaches copyright or violates any law, please contact openaccess@qub.ac.uk. 


\section{Clarification of rubber mill wastewater by a plant based biopolymer-}

\section{Comparison with common inorganic coagulants}

Sumona Mukherjee ${ }^{1}$, Agamuthu Pariatamby ${ }^{1}$, Jaya Narayan Sahu ${ }^{2 *}$, Bhaskar Sen Gupta ${ }^{3}$

Institute of Biological Sciences, University of Malaya, 50603, Kuala Lumpur, Malaysia

${ }^{2}$ Department of Chemical Engineering, University of Malaya, 50603, Kuala Lumpur,

Malaysia

${ }^{3}$ School of Planning, Architecture and Civil Engineering, Queen's University Belfast, David

Keir Building, Belfast, BT9 5AG, UK

* Corresponding Author:

Dr Jaya Narayan Sahu;

Department of Chemical Engineering,

Faculty of Engineering,

University of Malaya,

50603 Kuala Lumpur, Malaysia;

Phone: +600379675295 ;

Email: jnsahu@um.edu.my

This article has been accepted for publication and undergone full peer review but has not been through the copyediting, typesetting, pagination and proofreading process, which may lead to differences between this version and the Version of Record. Please cite this article as doi: $10.1002 /$ jctb.04041 


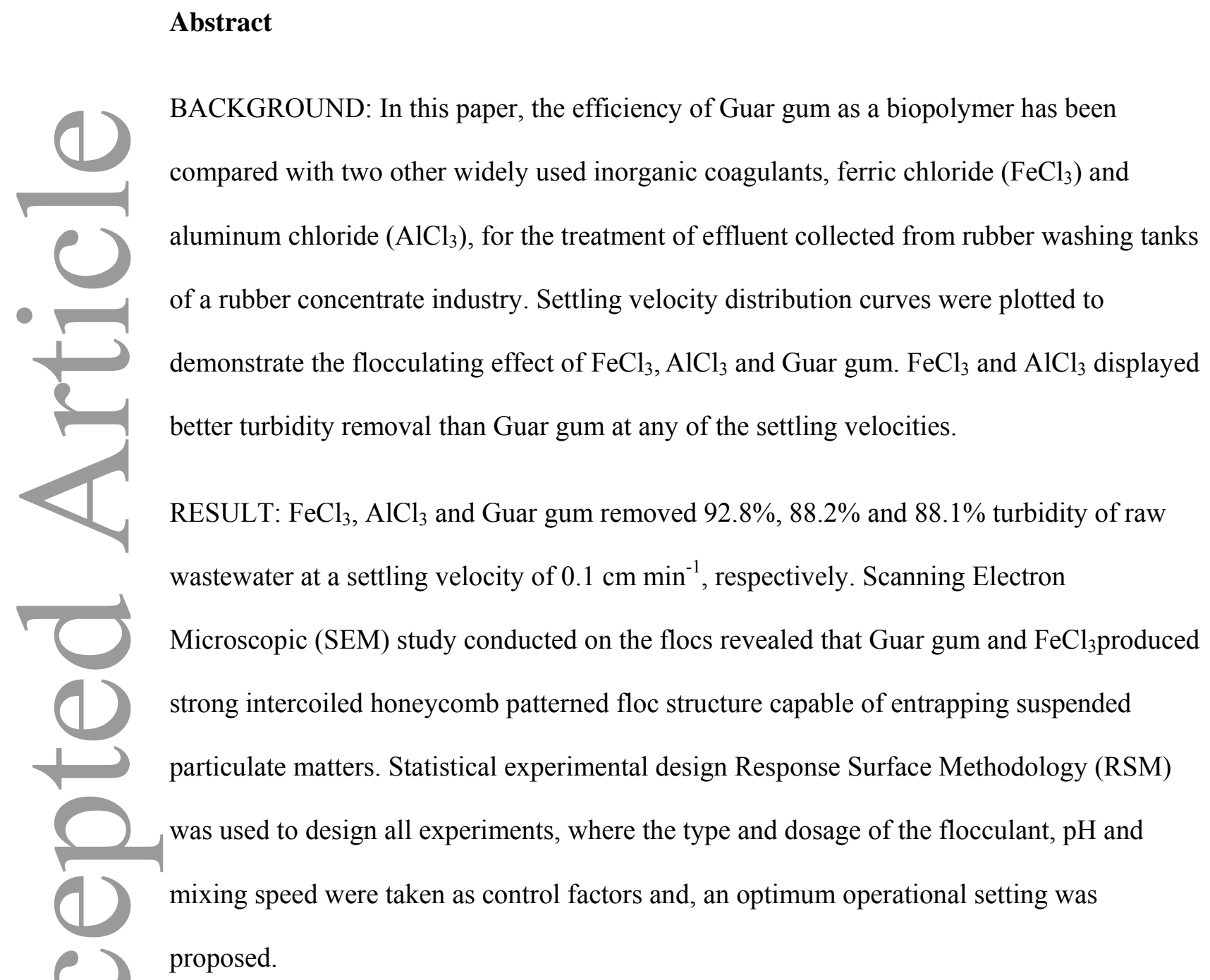

CONCLUSION: Due to biodegradability issues, the use of Guar gum as a flocculating agent for wastewater treatment in industries is highly recommended.

Keywords: biopolymer; biodegradable; wastewater treatment; flocculant; flocs 


\section{Introduction}

Most industrial processes produce by-products, which are considered to be sources of pollution and therefore require treatment. The treatment of industry waste increases production costs, therefore increasing the efficiency of this process is invaluable. ${ }^{1}$

Clarification of wastewater by flocculants is extensively used for wastewater treatment and is a simple and efficient process to operate. Many factors, such as the type and dosage of the flocculant, ${ }^{2-3}$ mixing speed, ${ }^{1,4-5}$ time, $\mathrm{pH}^{6-8}$ temperature ${ }^{6,9}$ and retention time etc., influence the efficiency of the wastewater clarification process. The optimization of these factors may considerably augment the efficiency of the process.

The rubber industry is one of Malaysia's most profitable industries, however it generates large quantities of wastewater that contains high concentrations of organic matter and suspended solids. ${ }^{10}$ For example, the wastewater generated from the latex concentrate industry contains a high organic load and generates malodor when discharged into receiving water bodies. ${ }^{11}$ Thus, treatment of wastewater is a necessary to prevent the release of harmful waste into the environment.

Most of the chemical flocculants used in wastewater treatment do not degrade naturally and are also costly to treat. The quantity of sludge produced by inorganic coagulants is also high. In this study, the potential use of Guar gum, a cheaper, naturally occurring and non-toxic biopolymer, as a flocculent aid in wastewater treatment has been investigated. The study compares the efficiency of Guar gum with respect to two commonly used chemical flocculants; ferric chloride $\left(\mathrm{FeCl}_{3}\right)$ and aluminium chloride $\left(\mathrm{AlCl}_{3}\right)$.

The present study is divided into two sections. In the first part, the effect of time on the settling of flocs at different $\mathrm{pH}$ and with different flocculants was studied. The data from three experimental runs were used to generate settling velocity distribution curves (SVDC). 
The second section aims to optimize the flocculant dosages, $\mathrm{pH}$ and mixing speed in order to achieve the highest removal efficiency of turbidity, using $\mathrm{FeCl}_{3}, \mathrm{AlCl}_{3}$ and Guar gum. The optimization is carried out via the Box Behnken RSM experimental design. The interactions between factors that influence the removal of turbidity were established, and model describing the effect of the factors on the removal of turbidity is also described.

\section{Methodology}

\subsection{Chemicals}

The wastewater was treated with two types of chemical coagulant and one biopolymer of plant origin. The inorganic chemical coagulants used were analytical grade $\mathrm{FeCl}_{3}$ and $\mathrm{AlCl}_{3}$. Separate $1 \mathrm{gml}^{-1}$ solutions were prepared for both $\mathrm{FeCl}_{3}$ and $\mathrm{AlCl}_{3}$. The plant origin coagulant used was food grade Guar gum, which is the grounded endosperm of Guar beans. Guar gum is a straight chain galactomannan that has galactose on every other mannose unit. The structure of Guar gum is shown in Figure 1.Guar gum is a biopolymer which can form bridge

between two or more particles at the same time and form aggregates called flocs. ${ }^{12}$ This plays an important role in the flocculation process. Fine grade category of Guar gum was used was used for the experiments. A solution of $1 \mathrm{gml}^{-1}$ was prepared using $0.1 \mathrm{gm}$ sample dissolved in $100 \mathrm{ml}$ of distilled water. To make an evenly wetted solution, the powder was added slowly to distilled water and the beaker containing the water was slowly shaken. New Guar gum solutions were prepared after every twelve hours to prevent growth of moulds. 


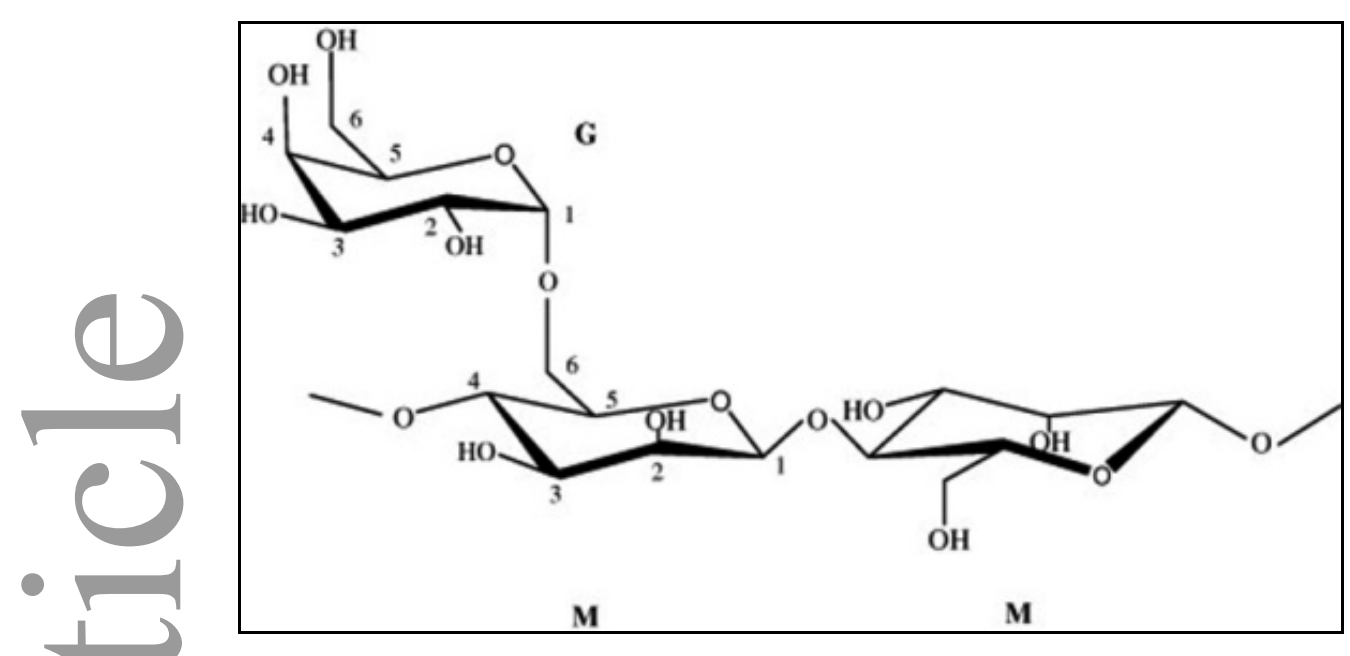

Fig 1. Chemical structure of Guar Gum ${ }^{13}$

\subsection{Wastewater sampling}

The wastewater was collected from a latex concentrate factory. In a latex concentrate factory the coagulated latex from the rubber field is severed into small pieces and washed to remove sand, dried wood, leaf pieces and other impurities to produce the latex concentrate.

Chemicals are not used during this process. The wastewater was collected from the outlet of rubber washing tank. The wastewater was stored in a refrigerator at $4^{\circ} \mathrm{C}$. The samples were not diluted for the experiments.

The characteristics of wastewater which was collected from the rubber concentrate industry is presented in Table 1. The wastewater, containing both inorganic substances as well as organic substances had a $\mathrm{pH}$ ranging between 7.3 to 7.4 and is within range of the Malaysian discharge standards. The temperature of the wastewater is $28^{\circ} \mathrm{C}$ which is much less than the Malaysian discharge standard. ${ }^{14}$ However, the wastewater contains about 867 and $228 \mathrm{mgl}^{-1}$ $\mathrm{COD}$ and $\mathrm{BOD}_{5}$ respectively, both of which are higher than the discharge standard. Also significant amount of colour, turbidity and bacterial count is present. The effluent in addition to this has a characteristic malodor. According to the Malaysian standards, the treatment of this wastewater is required before its discharge into any surface water body. 
Table 1. Characteristics of rubber industry effluent

\begin{tabular}{|c|c|c|c|c|}
\hline \multirow{21}{*}{ • } & Parameters & Concentration & Standard Deviation & Malaysian Standards \\
\hline & Temperature & $28.7^{\circ} \mathrm{C}$ & 0.14 & 40 \\
\hline & Conductivity & $2.793 \mathrm{mS}$ & 0.005 & - \\
\hline & pH & 7.33 & 0.05 & $6-9$ \\
\hline & Turbidity & 87.8NTU & 0.07 & - \\
\hline & Colour & 200TCU & 21.21 & 100 ADMI \\
\hline & T.A. & $19.8 \mathrm{mgl}^{-1}$ & 2.4 & - \\
\hline & D.O. & $0.23 \mathrm{mgl}^{-1}$ & 0.04 & - \\
\hline & COD & $867 \mathrm{mgl}^{-1}$ & 56.57 & $200 \mathrm{mgl}^{-1}$ \\
\hline & $\mathbf{B O D}_{5}$ & $228 \mathrm{mgl}^{-1}$ & 14.85 & $20 \mathrm{mgl}^{-1}$ \\
\hline & TOC & $0.04 \mathrm{mgl}^{-1}$ & 0.007 & - \\
\hline & Phenol & $0.44 \mathrm{mgl}^{-1}$ & 0.09 & $0.001 \mathrm{mgl}^{-1}$ \\
\hline & Hardness & $12.3 \mathrm{mgl}^{-1}$ & 1.9 & - \\
\hline & Total Nitrogen & $13.5 \mathrm{mgl}^{-1}$ & 2.12 & - \\
\hline & Ammonical N & $4.47 \mathrm{mgl}^{-1}$ & 0.06 & $10 \mathrm{mgl}^{-1}$ \\
\hline & Nitrate $\mathbf{N}$ & $1.10 \mathrm{mgl}^{-1}$ & 0.09 & - \\
\hline & Phosphate & $2.70 \mathrm{mgl}^{-1}$ & 0.28 & - \\
\hline & Sodium & $2.90 \mathrm{mgl}^{-1}$ & 0.21 & - \\
\hline & Potassium & $2.40 \mathrm{mgl}^{-1}$ & 0.28 & - \\
\hline & Iron & $3.85 \mathrm{mgl}^{-1}$ & 1.2 & $1 \mathrm{mgl}^{-1}$ \\
\hline & Total Bacterial Count & $130 \mathrm{CFU} / \mathrm{ml}$ & 49.5 & - \\
\hline
\end{tabular}

\subsection{Analytical methods used for physicochemical parameters}

The wastewater was first analyzed for various physico-chemical parameters, such as $\mathrm{pH}$, turbidity, conductivity, colour, alkalinity, Dissolved Oxygen (DO), COD, $\mathrm{BOD}_{5}$, total dissolved solids (TDS), total alkalinity (TA), Total Organic Carbon (TOC), phenol, hardness, total nitrogen, Ammoniacal N, Nitrate N, phosphate, sodium, potassium, iron and total bacterial count. The COD was analyzed through a standard dichromate closed reflux method. The concentration of heavy metals, such as Manganese and Iron, were measured using ICPOES. The other parameters were measured using standard methods. ${ }^{15}$ The experiments were carried out in duplicates under identical conditions. 


\subsection{Settling Velocity Distribution Curves}

A method, based on the same principles as that described by Hudson, ${ }^{16}$ was used to examine the settling characteristics of the flocculent suspensions produced. Three experimental runs were conducted and the $\mathrm{pH}$ of the three jars was adjusted to 8.5. After attaining the required $\mathrm{pH}$, the stirring paddles were lowered into the jars and the flocculent mixing design, starting with the highest speed of $185 \mathrm{rpm}$, was initiated. The samples were dosed with $1.75 \mathrm{mgl}^{-1}$ each of $\mathrm{FeCl}_{3}, \mathrm{AlCl}_{3}$ and Guar gum. Dosing was carried out as described in Section 2.6. According to Bartby ${ }^{17}$ there are several benefits of collecting samples according to this method. Problems faced during traditional sample collection techniques of column settling where floc size, permeability, and compressibility are measured, is easily avoided by doing away with handling operations. In this process the flocs are produced under controlled circumstances and collection of sample and analysis eliminates the requirement of any transferring operations during which floc breakage may occur. Twenty-five minutes after the initiation of flash mixing, the paddles of the jar tester were stopped. Samples were drawn from a fixed depth of $2 \mathrm{~cm}$ below the liquid surface of the flocculent suspension, at randomly chosen sampling times of $1,2,4,8,10,15,20,25$ and 30 minutes and analyzed for turbidity removal. New pipetting tips were used for each sample withdrawal. The results are shown in Table 5. 


\subsection{Experimental Design and Data analysis}

The experimental design, mathematical modeling and optimization studies were completed using Design Expert 7 software. Design Expert software facilitates the design and interpretation of multifactor experiments. It generates D-optimal designs so that existing designs can be improved or new designs created. The Box Behnken design was used to model the experiments and the design summary is presented in Table 2. Box Behnken designs are spherical designs characterized by set of second-order designs based on three-level incomplete factorial designs which are either rotatable or nearly rotatable. ${ }^{18}$ Within the spherical space Box Behnken design has excellent predictability and requires less number of experiments than other types of designs. The experimental design, as provided by the software, is given in Table 3.

The interaction between process variables and response was determined by graphically analyzing the data by Analysis of variance (ANOVA). The independent variables used in the study were; $\mathrm{pH}$, mixing speed and dose as numeric factors and $\mathrm{AlCl}_{3}, \mathrm{FeCl}_{3}$ and $\mathrm{Guar}$ gum represented categorical factors. They are coded as A, B, C and D respectively, as shown in Table 2. The range of variation of independent variables varied through $-1,0$ and +1 , and was fixed based on preliminary experiments and a literature survey. The same programme determined the quality of fit of the polynomial model, expressed by the coefficient of determination, $R^{2}$, and its statistical significance was checked by the Fisher $F$-test (Fisher variation ratio). Model terms were selected or rejected based on the $P$ value (probability) with a $95 \%$ confidence level. 
The interaction between three factors i.e., $\mathrm{pH}$, flocculant dose and mixing speed were shown in three-dimensional plots. The nature of interaction between two factors were also represented by the three dimensional plots.

The first step of RSM requires the addition of appropriate approximation, with the purpose of finding a true relationship between the set of independent variables (factors) and the dependent variable i.e., the response. According to Bayraktar ${ }^{19}$ a model is upgraded by adding higher order terms to the preliminary model when the linear model is insufficient to explain the shape of the response surface. Thus the linear model is then explained by a quadratic equation, as defined in Eq. (1). ${ }^{19-22}$

$$
y=\beta_{i}+\sum_{i=i}^{k} \beta_{i} X_{i}+\sum_{i=i}^{k} \beta_{i t} X_{i}^{2}+\sum_{i j i}^{k} \sum_{i}^{k} \beta_{i j} X_{i} X_{i}+s
$$

where $y$ is the response or dependent variable, $i$ and $j$ are linear and quadratic coefficients respectively, $\beta$ is the regression coefficient, $\mathrm{k}$ the number of factors studied and optimised in the experiment and $\varepsilon$ is the random error.

\section{Table 2. Experimental Design Summary}

\begin{tabular}{llllll}
\hline Factor & Name & Type & Low Actual & High Actual & Central Values (Zero level) \\
\hline A & $\mathrm{pH}$ & Numeric & 5 & 12 & 8.5 \\
\hline B & Mixing Speed & Numeric & $120 \mathrm{rpm}^{-1}$ & $250 \mathrm{rpm}$ & $185 \mathrm{rpm}$ \\
\hline C & Dose & Numeric & $1.5 \mathrm{mgl}^{-1}$ & $2 \mathrm{mgl}^{-1}$ & $1.75 \mathrm{mgl}^{-1}$ \\
\hline D & Coagulant & Categorical & $\mathrm{FeCl}_{3}$ & Guar Gum & $\mathrm{AlCl}_{3}$ \\
\hline
\end{tabular}


Table 3. Design of Experiment

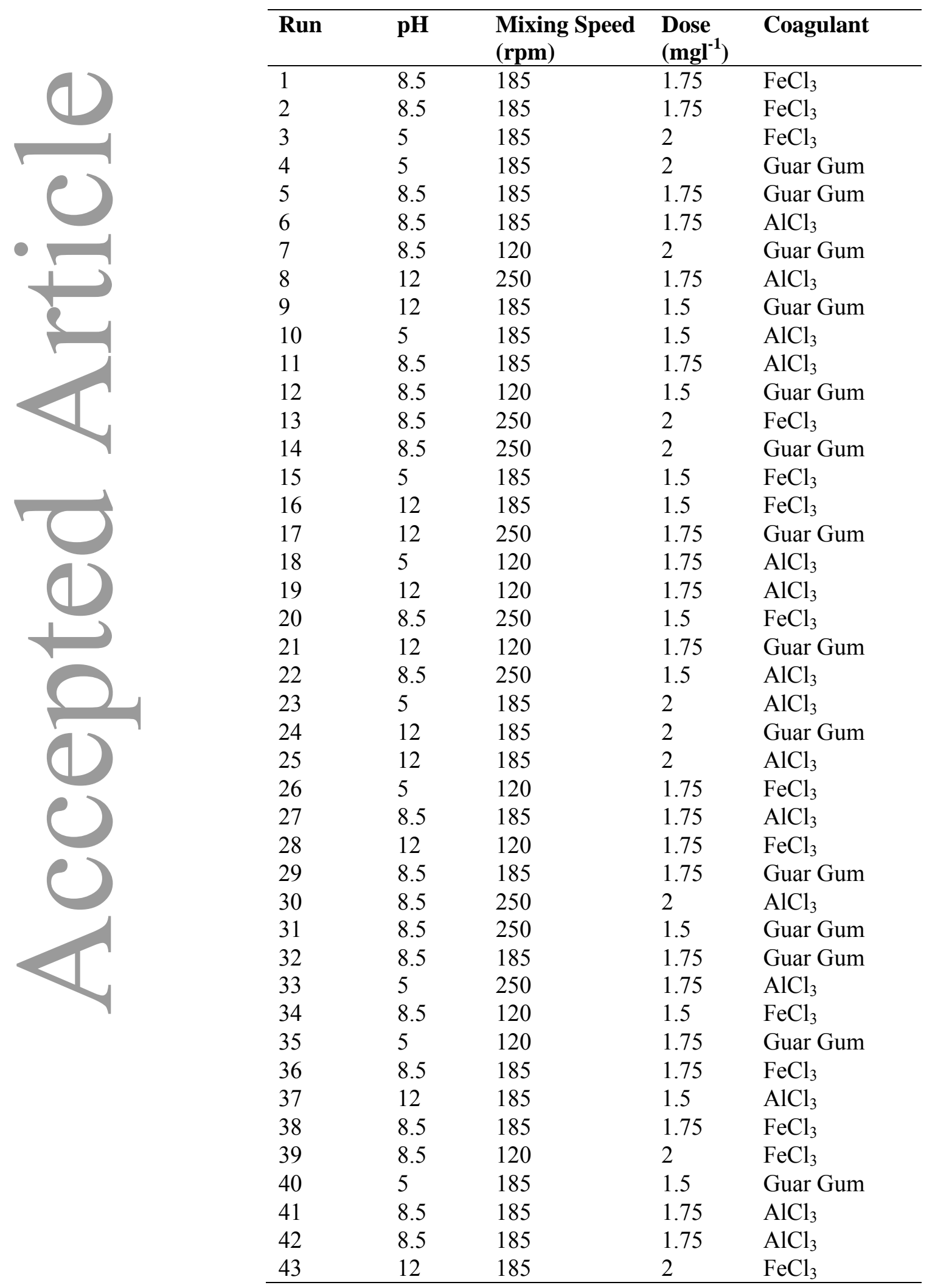




\begin{tabular}{lllll}
\hline 44 & 12 & 250 & 1.75 & $\mathrm{FeCl}_{3}$ \\
45 & 8.5 & 185 & 1.75 & $\mathrm{FeCl}_{3}$ \\
46 & 8.5 & 120 & 2 & $\mathrm{AlCl}_{3}$ \\
47 & 8.5 & 120 & 1.5 & $\mathrm{AlCl}_{3}$ \\
48 & 5 & 250 & 1.75 & $\mathrm{FeCl}_{3}$ \\
49 & 5 & 250 & 1.75 & Guar Gum \\
50 & 8.5 & 185 & 1.75 & Guar Gum \\
51 & 8.5 & 185 & 1.75 & Guar Gum \\
\hline
\end{tabular}

\subsection{Chemical clarification and flocculation}

Clarification of the wastewater was done using a jar test apparatus (Phipps and Bird PB-900 Programmable Jar Tester). The optimum concentration of Guar gum, $\mathrm{AlCl}_{3}$ and $\mathrm{FeCl}_{3}$ with respect to turbidity removal was determined through jar test studies. The treatment of wastewater was carried out in 500ml glass beakers at various dosages of the biopolymer and the two coagulants and analyzed. The $\mathrm{pH}$ of wastewater in each beaker was first adjusted to the required value by drop wise addition of $0.1 \mathrm{~N} \mathrm{HCl}$ or $\mathrm{NaOH}$ while the $\mathrm{pH}$ was recorded in a mobile $\mathrm{pH}$ meter (Metler Toledo Delta $320 \mathrm{pH}$ meter). After obtaining the desired $\mathrm{pH}$ levels, the beakers were placed on the jar test apparatus and the paddles were inserted into each beaker. The mixing was carried out in three phases. The stirring paddles were operated at maximum speed (flash mixing) in the first phase. Dosing of Guar gum, $\mathrm{AlCl}_{3}$ and $\mathrm{FeCl}_{3}$ was done two minutes after the beginning of flash mixing. For rapid dispersion the coagulants were dosed as close to the hub of the propeller as possible. The flash mixing was continued for another three minutes. The speed of the propeller was reduced in two phases. The design of the mixing speed is given in Table 4. The supernatant obtained after 30 minutes of settling was subjected to turbidity analysis in HACH $2100 \mathrm{~N}$ Turbidimeter. 
Table 4. Design of Mixing Speed

\begin{tabular}{lll}
\hline Phase 1(Flash Mixing) & Phase $2\left(\mathbf{1}^{\text {st }}\right.$ Slow mixing) & Phase $3\left(2^{\text {nd }}\right.$ Slow mixing $)$ \\
\hline $120 \mathrm{rpm}$ & $80 \mathrm{rpm}$ & $40 \mathrm{rpm}$ \\
$185 \mathrm{rpm}$ & $70 \mathrm{rpm}$ & $40 \mathrm{rpm}$ \\
$250 \mathrm{rpm}$ & $60 \mathrm{rpm}$ & $40 \mathrm{rpm}$ \\
\hline
\end{tabular}

\subsection{Physico-chemical characteristics of sludge}

The images from Scanning electron microscope (SEM) of the flocs, produced after the wastewater clarification, were obtained using the SEM microscope operating with SE2 detector of ZEISS Auriga Scanning electron microscope. The FTIR of the flocs and wastewater was studied in Bruker Vertex 70/70V spectrophotometer. Zeta potential of the treated water was measured in Zetasizer Nano ZS. The size of the flocs was measured by Malvern Mastersizer 2000.

\section{Results and Discussions}

\subsection{Settling Velocity Distribution Curves}

Table 5. Settling velocity vs measured turbidity at different time intervals and percent turbidity remaining

\begin{tabular}{rrrrrrrr}
\hline $\begin{array}{l}\text { Time } \\
(\mathrm{min})\end{array}$ & $\begin{array}{c}\text { Settling } \\
\text { velocity } \\
\left(\mathrm{cm} \mathrm{min}^{-1}\right)\end{array}$ & $\begin{array}{c}\text { Measured } \\
\text { turbidity } \\
\left(\mathrm{FeCl}_{3}\right)\end{array}$ & $\begin{array}{c}\text { Measured } \\
\text { turbidity } \\
\left(\mathrm{AlCl}_{3}\right)\end{array}$ & $\begin{array}{c}\text { Measured } \\
\text { turbidity } \\
(\mathrm{Guar} \\
\mathrm{Gum})\end{array}$ & $\begin{array}{c}\text { Percent } \\
\text { Turbidity } \\
\text { Remaining } \\
\left(\mathrm{FeCl}_{3}\right)\end{array}$ & $\begin{array}{c}\text { Percent } \\
\text { Turbidity } \\
\text { Remaining } \\
\left(\mathrm{AlCl}_{3}\right)\end{array}$ & $\begin{array}{c}\text { Percent } \\
\text { Turbidity } \\
\text { Remaining } \\
(\text { Guar gum })\end{array}$ \\
\hline 1 & 2 & 40 & 42 & 42 & 45.6 & 47.8 & 47.8 \\
2 & 1 & 25.36 & 35.3 & 36.9 & 28.9 & 40.2 & 42.0 \\
4 & 0.5 & 18.6 & 28.3 & 30.6 & 21.2 & 32.2 & 34.8 \\
8 & 0.25 & 10.21 & 18.9 & 19.8 & 11.6 & 21.5 & 22.5 \\
10 & 0.2 & 8.81 & 12 & 12.1 & 10.0 & 13.6 & 13.8 \\
15 & 0.133 & 7.85 & 9.68 & 10.6 & 8.9 & 11.0 & 12.1 \\
20 & 0.1 & 7.28 & 10.4 & 10.5 & 8.3 & 11.8 & 11.9 \\
25 & 0.08 & 7.63 & 10.7 & 10.4 & 8.7 & 12.2 & 11.8 \\
30 & 0.067 & 6.84 & 10.5 & 10.4 & 7.7 & 11.9 & 11.8 \\
\hline
\end{tabular}


The flocculating effect of $\mathrm{FeCl}_{3}, \mathrm{AlCl}_{3}$ and Guar gum were illustrated by the SVDCs (Fig 2).

The SDVC curves were generated by plotting 'percent turbidity remaining' (Tables 5) against the corresponding settling velocities. At arbitrarily chosen time intervals of 1, 2, 4, 8, 10, 20, 25 and $30 \mathrm{~min}$ and at settling velocities of $2,1,0.5,0.25,0.2,0.133,0.1,0.08$ and 0.067 $\mathrm{cmmin}^{-1}$, samples were drawn. The ratio of raw water turbidity remaining at the depth of sampling at the respective sampling time, can be calculated by dividing the raw water turbidity (87.8 NTU), by the measured turbidity of the samples withdrawn at the depth of sampling at fixed sampling time. The percent of raw water turbidity or the ratio thus defines the proportion of particulate matters that settle at a speed equal to or less than the corresponding settling velocity.

The highest percentage of raw water turbidity was first settled by $\mathrm{FeCl}_{3}$, followed by $\mathrm{AlCl}_{3}$, then Guar gum, at most of the settling velocities. As for example, at a settling velocity of $0.1 \mathrm{cmmin}^{-1}, 92.72 \%$ of raw water turbidity was settled by $\mathrm{FeCl}_{3}$. However, Guar gum was able to settle $89.5 \%$ of turbidity, a high level compared to conventional chemical coagulants. Given that Guar gum is a biodegradable and nontoxic organic compound, it is a good alternative to chemical coagulants. 

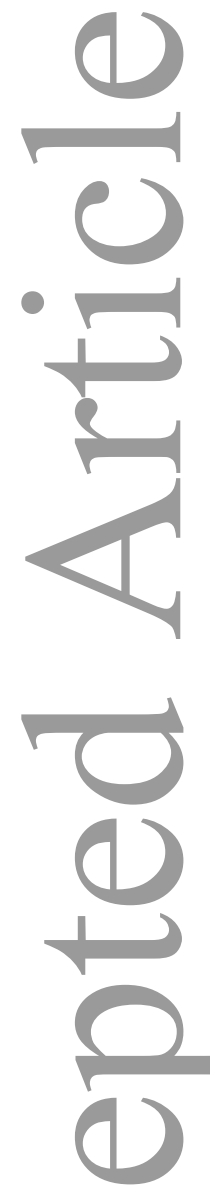

four factor, three level design that has three central points was designed. The effect of important operating variables on turbidity removal was investigated by using the Box-

Behnken statistical experimental design. 


\subsubsection{Optimization of supernatant turbidity}

The results of ANOVA for response surface reduced quadratic are presented in Table 6 .

Table 6 Statistical models obtained from the ANOVA for turbidity removal

\begin{tabular}{|c|c|c|c|c|c|c|}
\hline Source & Sum of Squares & DF & Mean Square & F Value & $\begin{array}{l}\text { p-value } \\
\text { Prob }>\text { F }\end{array}$ & \\
\hline Model & 4829.19 & 14 & 344.94 & 28.93 & $<0.0001$ & significant \\
\hline $\begin{array}{l}\text { A-pH } \\
\text { B-Mixing }\end{array}$ & 1641.43 & 1 & 1641.43 & 137.64 & $<0.0001$ & \\
\hline Speed & 964.06 & 1 & 964.06 & 80.84 & $<0.0001$ & \\
\hline C-Dose & 124.62 & 1 & 124.62 & 10.45 & 0.0026 & \\
\hline D-Coagulant & 186.46 & 2 & 93.23 & 7.82 & 0.0015 & \\
\hline $\mathrm{AB}$ & 50.06 & 1 & 50.06 & 4.19 & 0.0478 & \\
\hline $\mathrm{AC}$ & 119.64 & 1 & 119.63 & 10.03 & 0.0031 & \\
\hline $\mathrm{AD}$ & 171.29 & 2 & 85.64 & 7.18 & 0.0024 & \\
\hline $\mathrm{BD}$ & 42.38 & 2 & 21.19 & 1.78 & 0.1837 & \\
\hline $\mathrm{A}^{2}$ & 289.8 & 1 & 289.8 & 24.30 & $<0.0001$ & \\
\hline $\mathrm{B}^{2}$ & 905.34 & 1 & 905.3451 & 75.92 & $<0.0001$ & \\
\hline$C^{2}$ & 354.73 & 1 & 354.7318 & 29.74 & $<0.0001$ & \\
\hline Residual & 429.30 & 36 & 11.92 & & & \\
\hline Lack of Fit & 329.01 & 24 & 13.71 & 1.64 & 0.1868 & not significant \\
\hline Cor Total & 5258.496 & 50 & & & & \\
\hline Std. Dev. & 3.453279 & \multicolumn{2}{|c|}{ R-Squared } & 0.91836 & & \\
\hline Mean & 71.4349 & \multicolumn{2}{|c|}{ Adj R-Squared } & 0.886611 & & \\
\hline C.V. \% & 4.834162 & \multirow{2}{*}{\multicolumn{2}{|c|}{$\begin{array}{l}\text { Pred R-Squared } \\
\text { Adeq Precision }\end{array}$}} & 0.813634 & & \\
\hline PRESS & 980.0066 & & & 20.66342 & & \\
\hline
\end{tabular}

The following second order polynomial equations were obtained for the three coagulants $\mathrm{FeCl}_{3}, \mathrm{AlCl}_{3}$ and Guar Gum for turbidity removal by the three coagulants is as shown in supernatant solution: 


\section{$\mathrm{FeCl}_{3}$}

Turbidity $=-140.91352-13.09448 \times \mathrm{pH}+0.59649 \times$ Mixing Speed $+256.97481 \times$ Dose

$+0.39101 \times \mathrm{pH}^{2}-2.00379 \mathrm{E}-003 \times$ Mixing Speed ${ }^{2}-84.78933 \times \mathrm{Dose}^{2}+8.97802 \mathrm{E}-003 \times \mathrm{pH} \times$

Mixing Speed $+3.60857 \times \mathrm{pH} \times$ Dose

\section{$\mathrm{AlCl}_{3}$}

Turbidity $=-136.08255-12.43626 \times \mathrm{pH}+0.55295 \times$ Mixing Speed $+256.97481 \times$ Dose $+0.39101 \times \mathrm{pH}^{2}-2.00379 \mathrm{E}-003 \times$ Mixing Speed ${ }^{2}-84.78933 \times$ Dose $^{2}+8.97802 \mathrm{E}-003 \times \mathrm{pH} \times$ Mixing Speed $+3.60857 \times \mathrm{pH} \times$ Dose

\section{Guar Gum}

Turbidity $=-150.91476-11.24984 \times \mathrm{pH}+0.55330 \times$ Mixing Speed $+256.97481 \times$ Dose $+0.39101 \times \mathrm{pH}^{2}-2.00379 \mathrm{E}-003 \times$ Mixing Speed ${ }^{2}-84.78933 \times$ Dose $^{2}+8.97802 \mathrm{E}-003 \times \mathrm{pH}$ $\times$ Mixing Speed $+3.60857 \times \mathrm{pH} \times$ Dose

ANOVA is very important for testing the significance of a model. ${ }^{23}$ ANOVA is a statistical test which compares the means of several groups of data and finds if their mean are equal. In a regression analysis ANOVA determines the impact of independent variables on the dependent variables. As shown in Table 6, the ANOVA of regression model showed that quadratic model was highly significant for turbidity removal, as is evident from the Fisher's F-test $\left(\mathrm{F}_{\text {model }}=28.93\right)$, with a very low probability value $(\mathrm{P}$ model $>\mathrm{F}=0.0001)$, as suggested by Liu et al. ${ }^{24}$ There is only a $0.01 \%$ chance that a model value of this magnitude could occur due to noise. In the graph of the predicted values versus actual data values the 45 degree line 
should evenly split the data points. In this case (Fig 3 ) we see that the points are evenly distributed around the 45degree line.

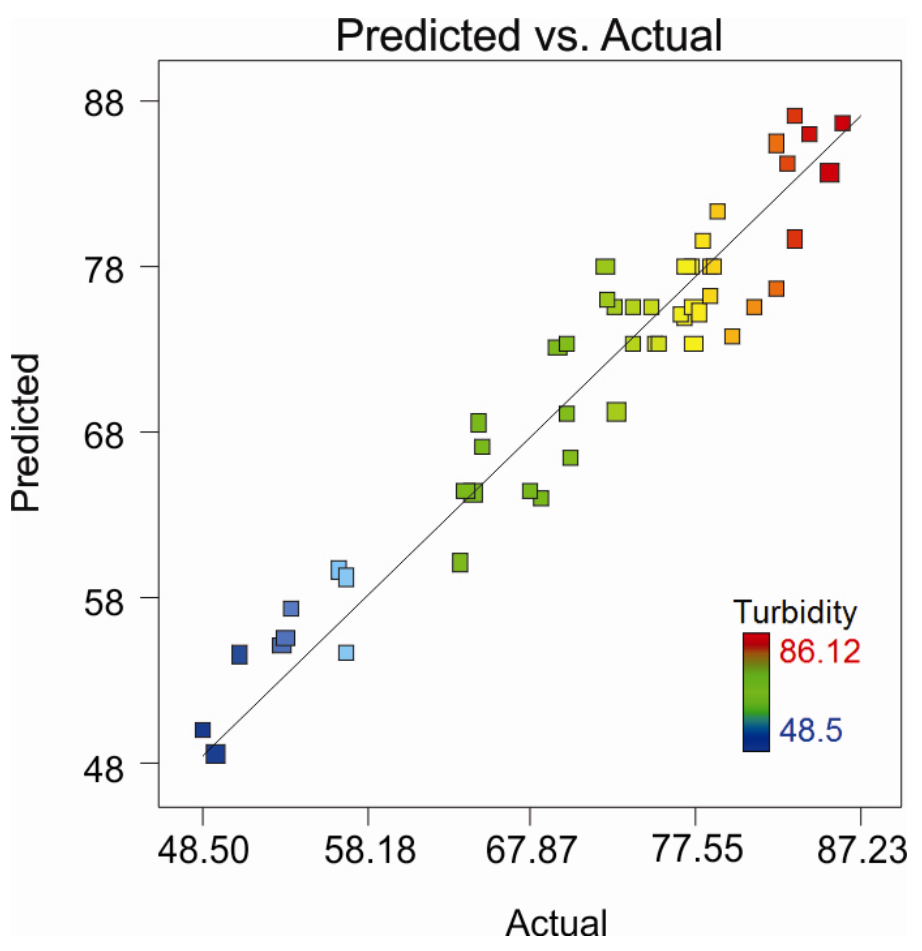

Fig 3. Predicted turbidity removal versus actual values

The accuracy of prediction of response value by a model can be measured by the Predicted $R^{2}$. For the model to be in sufficient a difference of no more than 0.20 should be there between. If the predicted and adjusted $R^{2}$ values are not within approximately 0.20 then there is an error in the model or the data. In the case of turbidity removal, the predicted $R^{2}$ value is 0.8136 , which is within reasonable agreement with the adjusted $R^{2}$ value of 0.8866 .

A signal to noise ratio of 4 or more is indicative of adequate precision, which is a measure of range of predicted response relative to the associated error. Normally the desired value is 4 or more. ${ }^{25-26}$ The ratio of 20.663 , in case of turbidity removal, indicates adequate signal. The error expressed as a percentage of the mean gives the coefficient of variation for this model. 


\subsubsection{Effect of Dose}

Response Surface plot for turbidity removal by $\mathrm{FeCl}_{3}, \mathrm{AlCl}_{3}$ and Guar gum is as shown in Figure 4, 5 and 6 respectively. The contour plot in Fig 4 implies that, as the concentration of $\mathrm{FeCl}_{3}$ increases from $1.5 \mathrm{mgl}^{-1}$, the turbidity removal increases. However it then decreases after $1.75 \mathrm{mgl}^{-1}$. The lowest turbidity removal is observed at a dose $2 \mathrm{mgl}^{-1}$. This observation is similar in the cases of $\mathrm{AlCl}_{3}$ and Guar gum. This re-suspension of solids at higher concentration should be the cause of low turbidity removal at higher dose. ${ }^{27}$ In addition, the high concentrations $(>1.75 \mathrm{mg} / \mathrm{L})$ of $\mathrm{FeCl}_{3}, \mathrm{AlCl}_{3}$ and Guar gum confer positive charges on the particle surface, thus re-dispersing the particles. ${ }^{28}$ According to the results of the Box-

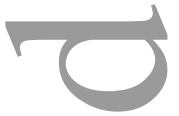
Behnken experimental design method, the optimum dose for maximum turbidity removal for $\mathrm{FeCl}_{3}, \mathrm{AlCl}_{3}$ and Guar gum was $1.64 \mathrm{mgl}^{-1}, 1.68 \mathrm{mgl}^{-1}, 1.69 \mathrm{mgl}^{-1}$ respectively. Also, at higher doses the conductivity increases, and thus increases the total dissolved solids, which is not a desirable effect. With the addition of chemical coagulants, the cataionic and anionic concentration of the solution increases. This increase in concentration cannot be removed from the supernatant liquid without anion or cation exchange. However, Guar gum is a natural biodegradable biopolymer and is not harmful to the environment as well as humans. 


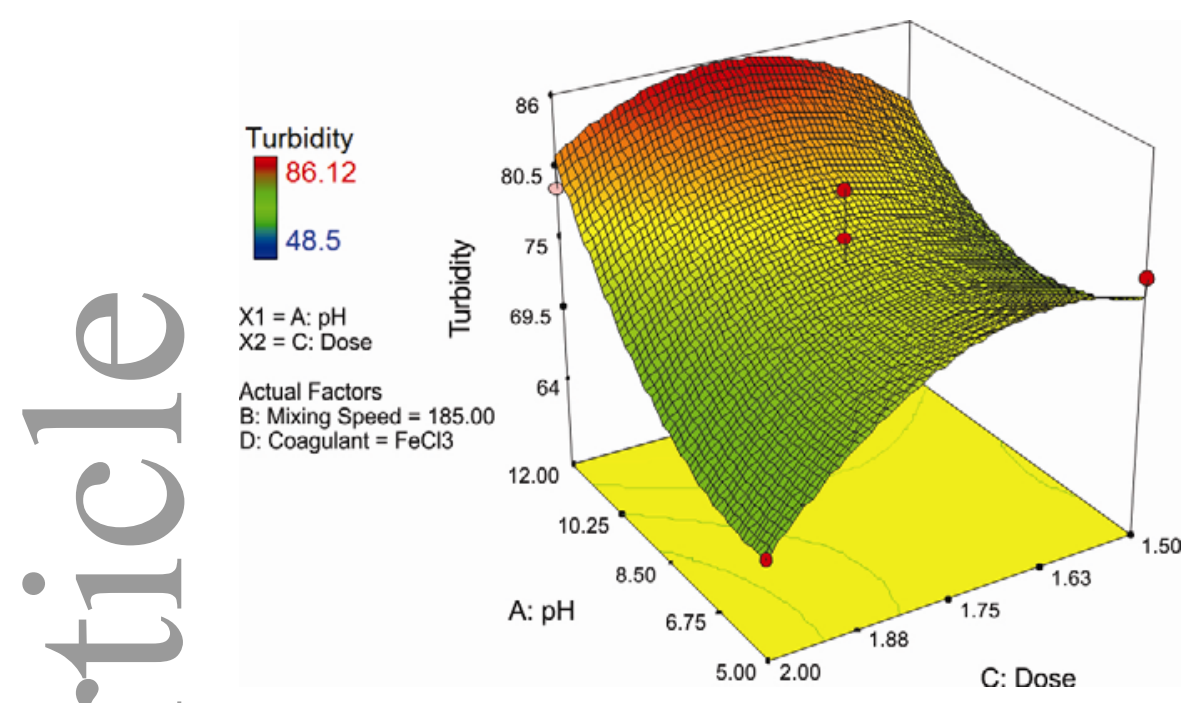

Fig 4. Response Surface plot of turbidity removal due to $\mathrm{FeCl}_{3}$ addition

\subsubsection{Effect of $\mathrm{pH}$}

The $\mathrm{pH}$ is one of the most important factor which influence clarification and is important because the addition of metallic cation (in this case $\mathrm{Fe}^{3+}$ and $\mathrm{Al}^{3+}$ ) causes lowering in $\mathrm{pH}$, which may lead to further decrease in the elimination of contaminants. According to the surface response curves (Fig 4, 5,6), as the $\mathrm{pH}$ of the solutions increase the turbidity removal first decreases and then increases. At $\mathrm{pH} 12$, the highest removal is achieved for all three coagulants. However, at $\mathrm{pH} 12$ the highest removal is also achieved at a dose of $2 \mathrm{mgl}^{-1}$. The need to add a higher dosage of flocculent may pose a health hazard, due to excessive use of chemicals. ${ }^{29}$ The excess residual chemical will then interfere with the survival and growth of aquatic life, when discharged into surface water. ${ }^{30}$ According to the Box-Behnken experimental design, at a $\mathrm{pH}$ of 5.82, 5.62 and 8.24 for $\mathrm{FeCl}_{3}, \mathrm{AlCl}_{3}$ and Guar gum respectively, the highest turbidity removal is achieved at a minimum dose of $1.5 \mathrm{mgl}^{-1}$. The percentage removal achieved at the optimum $\mathrm{pH}$ and at minimum dose of $1.5 \mathrm{mgl}^{-1}$, is $85.22 \%, 87.59 \%$ and $81.2 \%$ for $\mathrm{FeCl}_{3}, \mathrm{AlCl}_{3}$ and Guar gum respectively. The conductivity increases at very high and very low $\mathrm{pH}$, which is not desirable. 


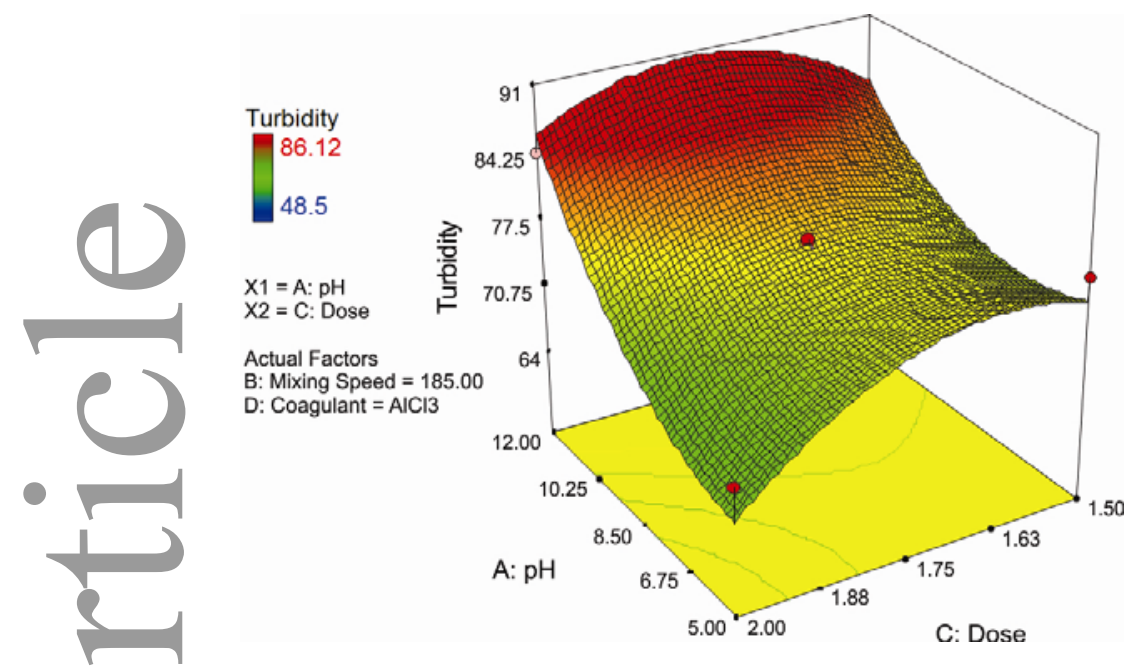

Fig 5. Response Surface plot of turbidity removal due to $\mathrm{AlCl}_{3}$ addition
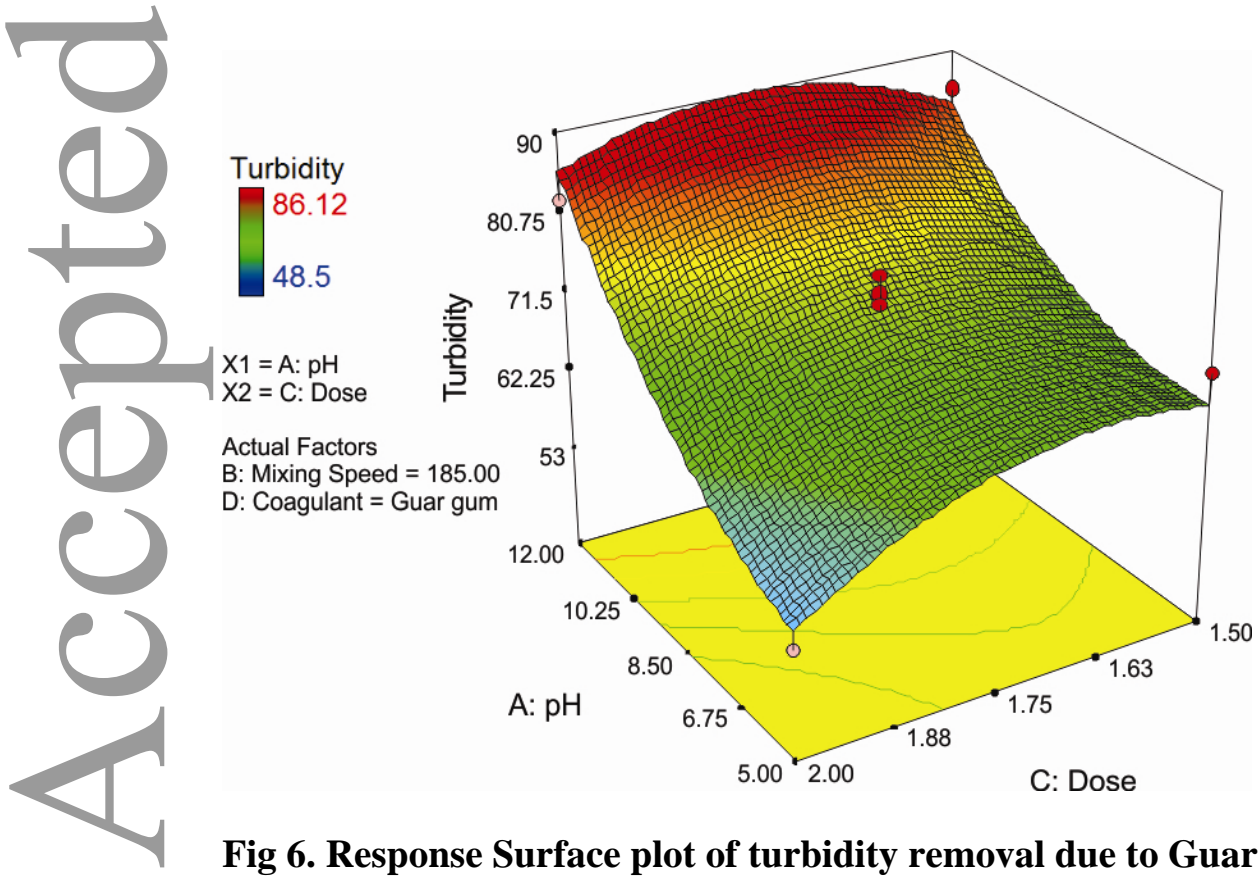

Fig 6. Response Surface plot of turbidity removal due to Guar Gum addition 


\subsubsection{Process optimization and model validation}

Optimization of turbidity removal was performed by a multiple response method called desirability function. Its purpose was to optimize different combinations of process parameters. The goal of optimization was to maximize turbidity removal performance by $\mathrm{FeCl}_{3}, \mathrm{AlCl}_{3}$ and Guar gum. To achieve maximum desirability of turbidity removal, for each coagulant separately, mixing speed was set within the experimental range, the $\mathrm{pH}$ was set at neutral and the dose was kept at a minimum value, as shown in Table 7, keeping in mind environmental sustainability and economic constraints. The optimum point of the factors was determined by additional experiments at the derived optimal conditions, conducted in three replicates. Table 7 shows the best processes for turbidity removal in the cases of $\mathrm{AlCl}_{3}, \mathrm{FeCl}_{3}$ and Guar gum. It can be concluded that the generated models were an adequate prediction of turbidity removal with relatively small errors, which were $3.97 \%, 4.01 \%$ and $3.92 \%$ for $\mathrm{AlCl}_{3}, \mathrm{FeCl}_{3}$ and Guar gum respectively.

\section{Table 7 Optimum conditions and their desirability}

\begin{tabular}{llllllll}
\hline & & $\begin{array}{l}\text { Mixing } \\
\text { Coagulant }\end{array}$ & $\mathrm{pH}$ & $\begin{array}{l}\text { Speed } \\
(\mathrm{rpm})\end{array}$ & $\begin{array}{l}\text { Dose } \\
\left(\mathrm{mgl}^{-1}\right)\end{array}$ & $\begin{array}{l}\text { Optimization } \\
\text { Turbidity }\end{array}$ & \multicolumn{3}{c}{ Removal } & Desirability & $\begin{array}{l}\text { Turbidity } \\
\text { Removal }\end{array}$ & Error (\%) \\
\hline $\mathrm{AlCl}_{3}$ & 7 & 153.68 & 1.5 & 75.91 & 0.90 & 78.92 & 3.97 \\
\hline $\mathrm{FeCl}_{3}$ & 7 & 164.5 & 1.5 & 73.40 & 0.87 & 76.34 & 4.01 \\
\hline Guar Gum & 7 & 153.86 & 1.5 & 69.44 & 0.82 & 66.71 & 3.92 \\
\hline
\end{tabular}




\subsection{Treatment of wastewater using flocculants- change of characteristics}

The characteristic of the wastewater after treatment with the flocculants is presented in Table 8. This can be compared with Table 1 in order to understand the improvement of water quality after treatment. For all the flocculants, viz. $\mathrm{FeCl}_{3}, \mathrm{AlCl}_{3}$ and $\mathrm{Guar}$ gum, the dose was kept at $1.75 \mathrm{mg} \mathrm{l}^{-1}$, the $\mathrm{pH}$ of the solution was maintained at 8.5 and the mixing speed was $185 \mathrm{rpm}$. After treatment, the $\mathrm{pH}$ remained near neutral for all the three treated wastewaters. The conductivity of the treated water slightly increased from $2.793 \mathrm{mS}$ of the original wastewater to $3.296 \mathrm{mS}, 2.928 \mathrm{mS}$ and $3.306 \mathrm{mS}$ due to addition of flocculants Guar gum, $\mathrm{FeCl}_{3}$ and $\mathrm{AlCl}_{3}$ respectively. Guar gum resulted in around 79.2\% $\mathrm{COD}$ removal which is comparable to the COD removal of $80.7 \%$ and $80.4 \%$ shown by $\mathrm{FeCl}_{3}$ and $\mathrm{AlCl}_{3}$ respectively. The $\mathrm{BOD}_{5}$ reduction is around $69 \%$ for Guar gum treated wastewater. This characterization study shows that Guar gum has potential for being used as a biopolymer instead of other synthetic agents. 
Table 8. Characterization of Wastewater after treatment with flocculants

\begin{tabular}{|c|c|c|c|c|}
\hline \multirow{21}{*}{ • } & Parameters & $\begin{array}{l}\text { Concentration } \\
\text { after treatment } \\
\text { with Guar gum }\end{array}$ & $\begin{array}{l}\text { Concentration after } \\
\text { treatment with } \\
\mathrm{FeCl}_{3}\end{array}$ & $\begin{array}{l}\text { Concentration after } \\
\text { treatment with } \\
\mathrm{AlCl}_{3}\end{array}$ \\
\hline & Temperature & $25^{\circ} \mathrm{C}$ & $25^{\circ} \mathrm{C}$ & $25^{\circ} \mathrm{C}$ \\
\hline & Conductivity & $3.296 \mathrm{mS}$ & $2.928 \mathrm{mS}$ & $3.306 \mathrm{mS}$ \\
\hline & pH & 7.65 & 7.03 & 7.45 \\
\hline & Turbidity & 10.4 NTU & $6.84 \mathrm{NTU}$ & $10.5 \mathrm{NTU}$ \\
\hline & Colour & $170 \mathrm{TCU}$ & 140 TCU & $160 \mathrm{TCU}$ \\
\hline & T.A. & $18.7 \mathrm{mgl}^{-1}$ & $10.3 \mathrm{mgl}^{-1}$ & $12.4 \mathrm{mgl}^{-1}$ \\
\hline & D.O. & - & - & - \\
\hline & COD & $180 \mathrm{mgl}^{-1}$ & $167 \mathrm{mgl}^{-1}$ & $170 \mathrm{mgl}^{-1}$ \\
\hline & BOD $_{5}$ & $70 \mathrm{mgl}^{-1}$ & $65 \mathrm{mgl}^{-1}$ & $68 \mathrm{mgl}^{-1}$ \\
\hline & TOC & $0.03 \mathrm{mgl}^{-1}$ & $0.02 \mathrm{mgl}^{-1}$ & $0.03 \mathrm{mgl}^{-1}$ \\
\hline & Phenol & $0.42 \mathrm{mgl}^{-1}$ & $0.43 \mathrm{mgl}^{-1}$ & $0.44 \mathrm{mgl}^{-1}$ \\
\hline & Hardness & $10.3 \mathrm{mgl}^{-1}$ & $11 \mathrm{mgl}^{-1}$ & $10.8 \mathrm{mgl}^{-1}$ \\
\hline & Total Nitrogen & $8.25 \mathrm{mgl}^{-1}$ & $6.25 \mathrm{mgl}^{-1}$ & $7.07 \mathrm{mgl}^{-1}$ \\
\hline & Ammonical $\mathbf{N}$ & - & - & - \\
\hline & Nitrate $\mathbf{N}$ & $1 \mathrm{mgl}^{-1}$ & $1.1 \mathrm{mgl}^{-1}$ & $0.85 \mathrm{mgl}^{-1}$ \\
\hline & Phosphate & $2.7 \mathrm{mgl}^{-1}$ & $2.7 \mathrm{mgl}^{-1}$ & $2.75 \mathrm{mgl}^{-1}$ \\
\hline & Sodium & $3.05 \mathrm{mgl}^{-1}$ & $3.45 \mathrm{mgl}^{-1}$ & $3.25 \mathrm{mgl}^{-1}$ \\
\hline & Potassium & $2.3 \mathrm{mgl}^{-1}$ & $2.5 \mathrm{mgl}^{-1}$ & $2.35 \mathrm{mgl}^{-1}$ \\
\hline & Iron & $2.85 \mathrm{mgl}^{-1}$ & $4.07 \mathrm{mgl}^{-1}$ & $2.67 \mathrm{mgl}^{-1}$ \\
\hline & Total Bacterial Count & $120 \mathrm{CFU} / \mathrm{ml}$ & $110 \mathrm{CFU} / \mathrm{ml}$ & $110 \mathrm{CFU} / \mathrm{ml}$ \\
\hline
\end{tabular}




\subsection{Physico chemical characteristics of flocs}

\subsubsection{FTIR spectral analysis}

The FTIR analysis (Fig 7) shows that the occurrence of different functional groups in the flocs and Guar gum. The FTIR spectra of the wastewater also shows the presence of different functional groups. It can thus be concluded that physicochemical interaction between the wastes present in the wastewater and cations and active groups from the chemical coagulants and biopolymer respectively, resulted in the removal of suspended particulates during clarification process. In this case the location of peaks in the case of different flocs of $\mathrm{FeCl}_{3}$, $\mathrm{AlCl}_{3}$ and Guar gum was the same, however relative intensity of transmittance varied in FTIR spectra. The FTIR spectrum of rubber industry wastewater exhibits a broad band at $3222.03 \mathrm{~cm}^{-1}$, due to $v(\mathrm{OH})$ present in the water. Another peak at $2172.56 \mathrm{~cm}^{-1}$ exhibits the presence of $\mathrm{C} \equiv \mathrm{N}$ stretching of thiocyanate $(\mathrm{SCN})$. The dried flocs displayed peaks in the range of $3000-3500 \mathrm{~cm}^{-1}$, indicating the presence of $v(\mathrm{OH})$. C-O stretching between 1075$1000 \mathrm{~cm}^{-1}$ was also found in all the flocs, indicating the presence of alkyl alcohols. The FTIR spectra of the flocs showed similar sharp and average peaks in the range $560-830 \mathrm{~cm}^{-1}$, indicating the presence of organic halides. Hence, it is shown that the halides are removed during the treatment process. It may be concluded from FTIR analysis that there is a resemblance in peaks observed between rubber industry wastewater and the treated flocs, with little shift in the location of the peaks. It confirms that some inherent complex physicalchemical phenomenon was responsible for different components of wastewater getting attached onto coagulants, resulting in the removal of wastewater turbidity. 


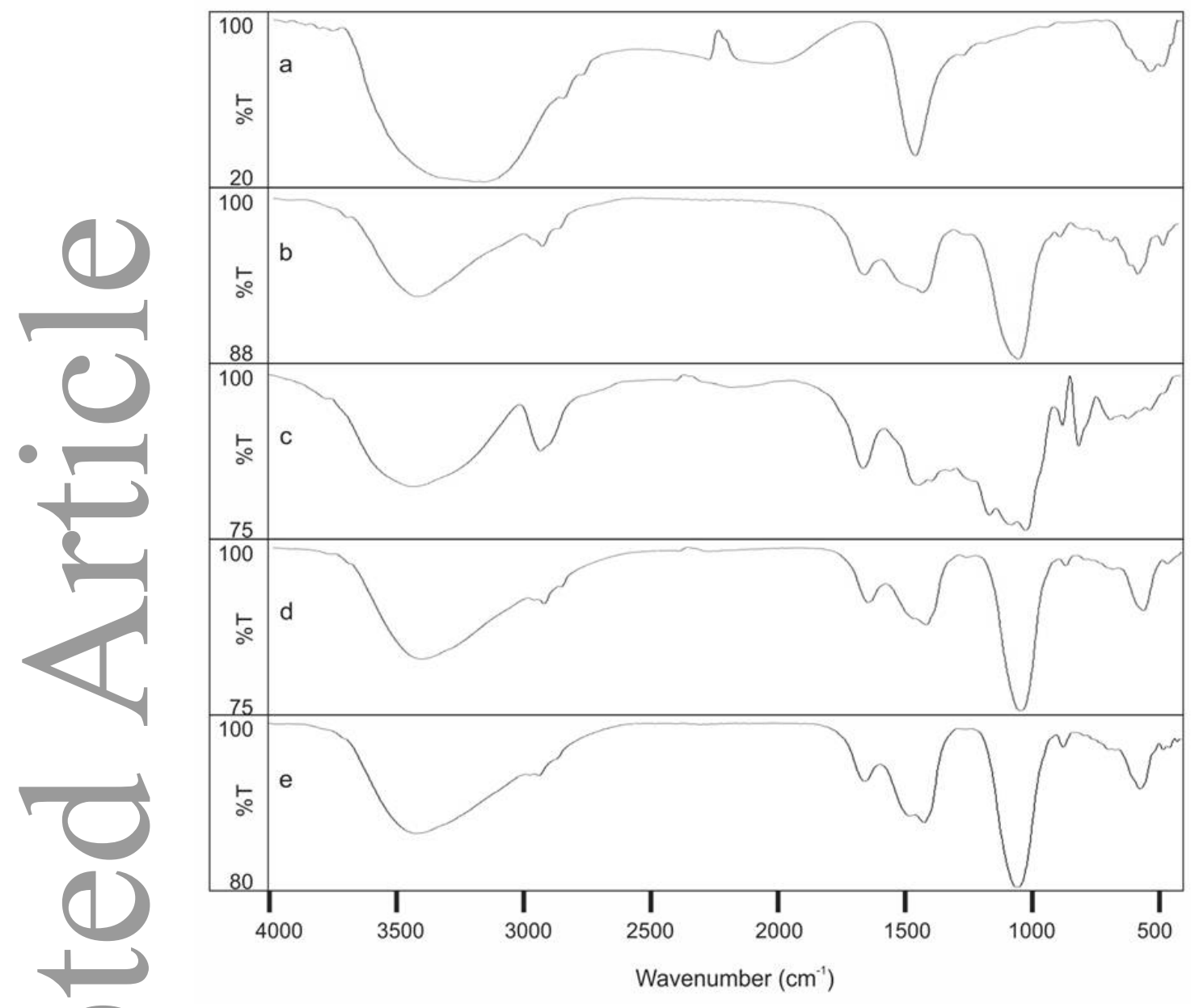

Fig 7. FTIR spectra of (a) rubber industry wastewater (b)flocs obtained by Guar Gum, (c) Guar Gum powder, (d) flocs obtained by $\mathrm{FeCl}_{3}$ and (e) flocs obtained by $\mathrm{AlCl}_{3}$

\subsubsection{SEM micrographs}

The SEM micrographs are presented in Fig 8. It can be inferred from the micrographs that the flocs generated after the treatment of the wastewater with Guar gum and $\mathrm{FeCl}_{3}$ are porous and have more surface area as opposed to the flocs produced by $\mathrm{AlCl}_{3}$. A strong intercoilled honeycombed pattern was observed in the two cases, with suspended particulate matter entrapped in it, indicating the sweep flocculation of the suspended particles in the wastewater. The characteristic flocs produced by Guar gum indicate that it can be used effectively used for wastewater treatment. 


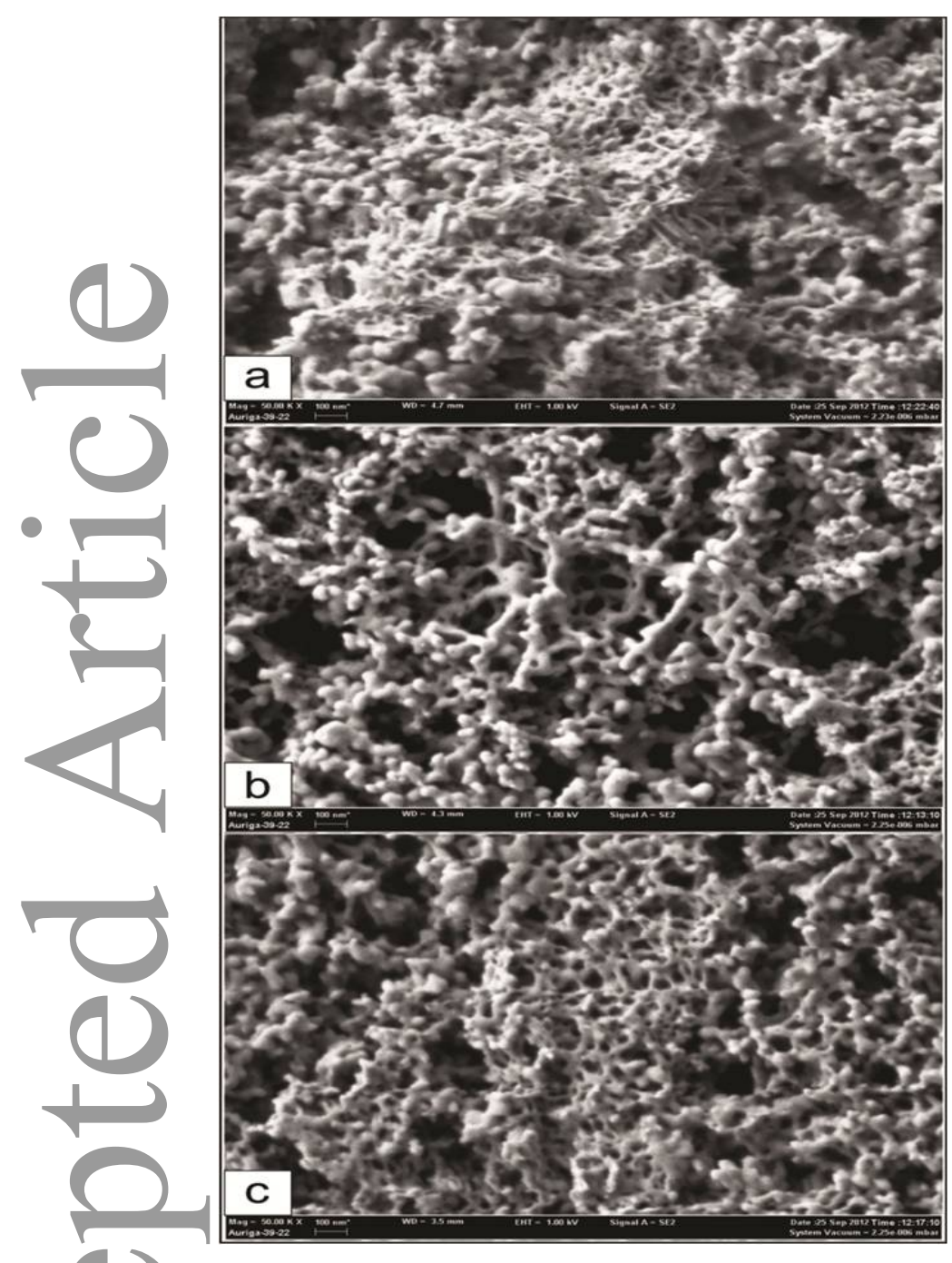

Fig 8 SEM images for (a)AlCl 3 , (b)FeCl ${ }_{3}$ and (c) Guar gum Flocs

\subsubsection{Zeta potential and particle size distribution study}

Guar gum is a long chain polymer with no dissociable functional groups so it is neutrally

charged. ${ }^{31}$ On the other hand the zeta potential of the wastewater is negative $(-17.1 \mathrm{mV})$. After addition of Guar gum the zeta potential of the wastewater increases to $-12.8 \mathrm{mV}$. This can be attributed to the fact that Guar gum gets adsorbed on the surface of the particles during flocculation and masks the negative charge on the particles. ${ }^{32}$ This increase in zeta potential leads to the flocculation of waste particles. The zeta potential of the water after addition of $\mathrm{FeCl}_{3}$ and $\mathrm{AlCl}_{3}$ increases to $-9.89 \mathrm{mV}$ and $-12.9 \mathrm{mV}$ respectively. Table 9 gives the variation 
of zeta potential at a fixed coagulant dose of $1.75 \mathrm{mgl}^{-1}$ and at different $\mathrm{pH}$ values. Figure 9 shows the particle size distribution of the flocs for the three coagulants.

Table 9 Zeta potential of wastewater after addition of coagulants

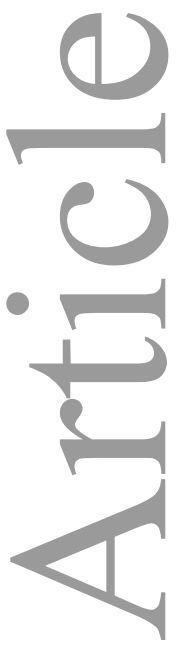

\begin{tabular}{llll}
\hline Coagulant & $\begin{array}{l}\text { Dose } \\
\left(\mathrm{mgl}^{-1}\right)\end{array}$ & $\mathbf{p H}$ & $\begin{array}{l}\text { Zeta Potential } \\
(\mathbf{m V})\end{array}$ \\
\hline Guar gum & 1.75 & 5 & -13.1 \\
& & 8.5 & -14.4 \\
& 12 & -12.8 \\
\hline $\mathrm{FeCl}_{3}$ & 5 & -13.4 \\
& 8.5 & -14.2 \\
$\mathrm{AlCl}_{3}$ & 12 & -9.8 \\
& 5 & -16.8 \\
& 8.5 & -15.4 \\
& 12 & -12.9
\end{tabular}
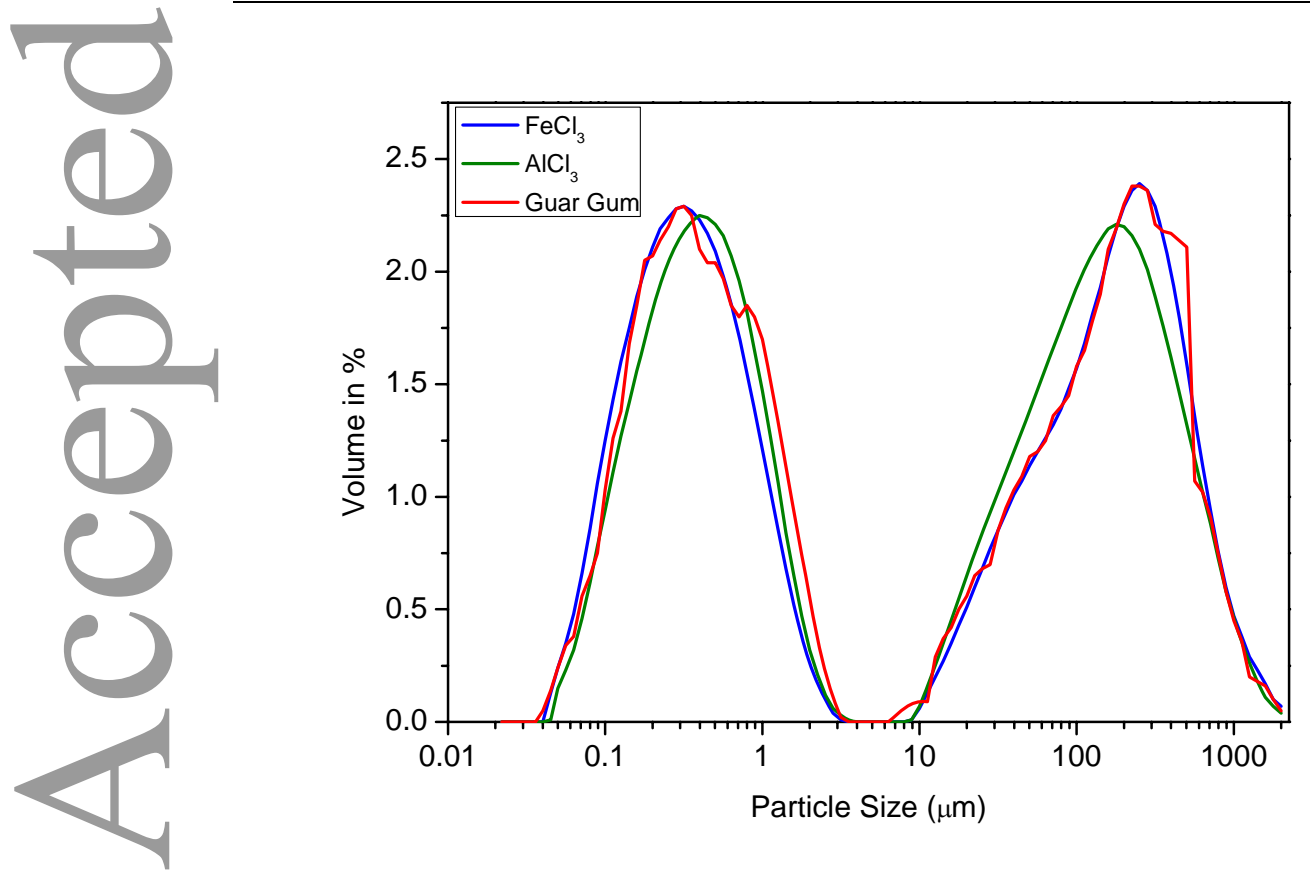

Figure 9 Particle size distribution of flocs 


\section{Conclusion}

This work presents the performance of a biopolymer and two chemical coagulants in treating rubber industry effluent. Statistical design was able to exhibit the influence of significant design parameters on the turbidity removal process. ANOVA showed a high $\mathrm{R}^{2}$ value of 0.92 for the regression model equation, which shows sufficient agreement of the model with the experimental data. A quadratic model was able to explain the performance of the coagulants in turbidity removal with a high level of significance. Guar gum was effective in removing $88.2 \%$ of turbidity compared to $93.16 \%$ removal by a chemical coagulant $\mathrm{FeCl}_{3}$. The SEM micrographs also showed that Guar gum produces porous and strong flocs and is capable of turbidity removal in sweep flocculation. Since Guar gum has a natural origin, is biodegradable ${ }^{33}$ and non-toxic, ${ }^{34}$ it can be used to replace $\mathrm{FeCl}_{3}$ in the industrial wastewater treatment process. Also as there is around $88 \%$ turbidity removal the water after treatment may be further reused for washing purposes.

\section{Acknowledgements}

The authors are grateful to University of Malaya (HIR Project No:

$\mathrm{UMC} / \mathrm{HIR} / \mathrm{MOHE} / \mathrm{ENG} / 13)$, Malaysia for providing the financial support for executing the work. 


\section{References:}

1. Rossini M, Garrido JG and Galluzzo M, Optimization of the coagulation-flocculation treatment: influence of rapid mix parameters. Water Research 33: 1817-1826 (1999).

2. Spicer PT and Pratsinis SE, Shear-induced flocculation: The evolution of floc structure and the shape of the size distribution at steady state. Water Research 30: 1049-1056 (1996).

3. Al-Malack MH and Anderson GK, Coagulation-crossflow microfiltration of domestic wastewater. Journal of Membrane Science 121: 59-70 (1996).

4. Nandy T, Shastry S, Pathe PP and Kaul SN, Pre-Treatment of Currency Printing Ink Wastewater through Coagulation-Flocculation Process. Water, Air, \& Soil Pollution 148: 1530 (2003).

5. Domínguez JR, Beltrán de Heredia J, González T and Sanchez-Lavado F, Evaluation of Ferric Chloride as a Coagulant for Cork Processing Wastewaters. Influence of the Operating Conditions on the Removal of Organic Matter and Settleability Parameters. Industrial \& Engineering Chemistry Research 44: 6539-6548 (2005).

6. Desjardins C, Koudjonou B and Desjardins R, Laboratory study of ballasted flocculation. Water Research 36: 744-754 (2002).

7. Elmaleh S, Yahi H and Coma J, Suspended solids abatement by $\mathrm{pH}$ increase-upgrading of an oxidation pond effluent. Water Research 30: 2357-2362 (1996).

8. Rohrsetzer S, Pászli I and Csempesz F, Colloid stability of electrostatically stabilized sols. Colloid \& Polymer Science 276: 260-266 (1998).

9. Gürses A, Yalçin M and Dogar C, Removal of Remazol Red Rb by using Al (III) as CoagulantFlocculant: Effect of Some Variables on Settling Velocity. Water, Air, \& Soil Pollution 146: 297-318 (2003).

10. Rakkoed A, Danteravanich S and Puetpaiboon U, Nitrogen removal in attached growth waste stabilization ponds of wastewater from a rubber factory. Water Science and Technology 40: 45-52 (1999).

11. Kumlanghan A, Kanatharana P, Asawatreratanakul P, Mattiasson B and Thavarungkul $P$, Microbial BOD sensor for monitoring treatment of wastewater from a rubber latex industry. Enzyme and Microbial Technology 42: 483-491 (2008).

12. Sanghi R, Bhattacharya B and Singh V, Seed gum polysaccharides and their grafted copolymers for the effective coagulation of textile dye solutions. Reactive and Functional Polymers 67: 495-502 (2007).

13. Ding B, Ye Yq, Cheng J, Wang K, Luo J and Jiang B, TEMPO-mediated selective oxidation of substituted polysaccharides-an efficient approach for the determination of the degree of substitution at C-6. Carbohydrate Research 343: 3112-3116 (2008).

14. DoE, Environmental Requiremnts: A guide for Investors, ed by Environment Do, Putrajaya (2010).

15. APHA, StandardMethods for the Examination of Water and Wastewater, ed by Inc APHA, Washington DC, USA (1995).

16. Hudson HJ, Water Clarification Processes: Practical Design and Evaluation, in Van Nostrand Environmental Engineering Series, London, UK (1981).

17. Bartby J, Optimizing coagulants and flocculant-aids for settling. J Am Water Works Assoc (1981).

18. Ferreira SLC, Bruns RE, Ferreira HS, Matos GD, David JM, Brandão GC, da Silva EGP, Portugal LA, dos Reis PS, Souza AS and dos Santos WNL, Box-Behnken design: An alternative for the optimization of analytical methods. Analytica Chimica Acta 597: 179-186 (2007).

19. Bayraktar $E$, Response surface optimization of the separation of dl-tryptophan using an emulsion liquid membrane. Process Biochemistry 37: 169-175 (2001). 
20. Adinarayana $\mathrm{K}$ and Ellaiah $\mathrm{P}$, Response surface optimization of the critical medium components for the production of alkaline protease by a newly isolated Bacillus sp. J Pharm Pharm Sci 5: 272-278 (2002).

21. Can MY, Kaya Y and Algur OF, Response surface optimization of the removal of nickel from aqueous solution by cone biomass of Pinus sylvestris. Bioresource Technology 97: 1761-1765 (2006).

22. Montgomery DC, Design and Analysis of Experiments. John Wiley and Sons, New York (2001).

23. Sen R and Swaminathan T, Response surface modeling and optimization to elucidate and analyze the effects of inoculum age and size on surfactin production. Biochemical Engineering Journal 21: 141-148 (2004).

24. Liu H-L, Lan Y-W and Cheng Y-C, Optimal production of sulphuric acid by Thiobacillus thiooxidans using response surface methodology. Process Biochemistry 39: 1953-1961 (2004).

25. Aghamohammadi N, Aziz $\mathrm{HbA}$, Isa $\mathrm{MH}$ and Zinatizadeh AA, Powdered activated carbon augmented activated sludge process for treatment of semi-aerobic landfill leachate using response surface methodology. Bioresource Technology 98: 3570-3578 (2007).

26. Mason RL, Gunst RF and Hess JL, Frontmatter, in Statistical Design and Analysis of Experiments. John Wiley \& Sons, Inc., pp. i-xix (2003).

27. Abdel-Shafy $\mathrm{HI}$ and O. Abo-El-Wafa MAA, Chemical treatment of industrial effluent, in International Conference Heavy Metals in the Environment, New Orleans, pp. p. 452 (1987).

28. Kemmer FNE, The Nalco Water Handbook of Coagulation and Flocculation., in Unit Operations of Water Treatment,second ed, McGraw-Hill Book Company (1988).

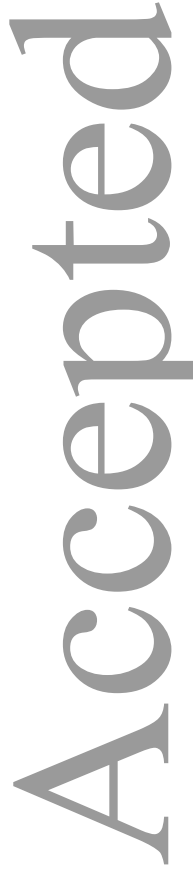

29. UK DOE, Recommended Maximum Chemical Additives Dosage, ed by Environment Do. DOE (1984).

30. AWWA, Updates of the State of the Art: Report of the AWWA Sludge Disposal CommitteePart 2. J. Am. Water Workers Assoc. , pp. 3-5. (1978).

31. Tiraferri A, Chen KL, Sethi R and Elimelech M, Reduced aggregation and sedimentation of zero-valent iron nanoparticles in the presence of guar gum. Journal of Colloid and Interface Science 324: 71-79 (2008).

32. Wang J, Somasundaran P and Nagaraj DR, Adsorption mechanism of guar gum at solid-liquid interfaces. Minerals Engineering 18: 77-81 (2005).

33. Prasad YVR, Krishnaiah YSR and Satyanarayana S, In vitro evaluation of guar gum as a carrier for colon-specific drug delivery. Journal of Controlled Release 51: 281-287 (1998).

34. Sen Gupta B and Ako J, Application of guar gum as a flocculant aid in food processing and potable water treatment. European Food Research and Technology 221: 746-751 (2005). 